Review

\title{
Second line therapy in malignant pleural mesothelioma: A systematic review
}

\author{
Wieneke A. Buikhuisen ${ }^{\mathrm{a}, 1}$, Birgitta I. Hiddinga ${ }^{\mathrm{b}, 1}$, Paul Baas ${ }^{\mathrm{a}, 2}$, Jan P. van Meerbeeck ${ }^{\mathrm{b}, *, 2}$ \\ a Thoraxoncologie, Nederlands Kanker Instituut, Amsterdam, The Netherlands \\ b Thoraxoncologie, Universitair Ziekenhuis Antwerpen, Belgium
}

\section{A R T I C L E I N F O}

\section{Article history:}

Received 22 May 2015

Accepted 21 June 2015

\section{Keywords:}

Mesothelioma

Treatment

Chemotherapy

Second line

Biological

Targeted treatment

Outcome

Meta-analysis

\begin{abstract}
A B S T R A C T
After the implementation of standard first line chemotherapy with platinum and antifolates in pleural mesothelioma, patients are confronted with a need for second line treatment at relapse or progression. We conducted a systematic review of the literature for the activity, effectiveness and toxicity of second line treatment. The results are presented according to the class of drugs: chemotherapy and targeted or biological agent.
\end{abstract}

(C) 2015 Elsevier Ireland Ltd. All rights reserved.

\section{Introduction}

Malignant pleural mesothelioma (MPM) is a cancer of the surface mesothelium of the pleural cavity. Over $80 \%$ of mesothelioma patients have a history of previous intense occupational asbestos exposure. A causal relation has been repeatedly documented, although MPM can also result from very low levels of environmental exposure [1]. The average latency of $40-45$ years or more since the start of the exposure as found in studies with adequately long follow-up time explains the pattern of the observed mesothelioma incidence increases over the last decades with an estimated 43,000 annual deaths worldwide and why substantial decreases are not expected before 2020 [2]. Time trends indicate a slow shift of disease burden to countries consuming asbestos most recently [3], while incidence has peaked in most western industrialized countries after the ban of asbestos import and use in the eighties and nineties of last century [4]. Other possible causes are ionizing radiation, endemic erionite exposure and chronic inflammation of the pleura [3].

MPM has a poor prognosis: most patients will die of their disease within less than one year of diagnosis, if untreated. Among the

\footnotetext{
* Corresponding author at: MOCA, Wilrijkstraat 10, 2650 Edegem, Belgium.

E-mail address: p.baas@nki.nl (J.P. van Meerbeeck).

1 These authors contributed equally to this manuscript.

2 Joint senior authors.
}

reasons for this detrimental natural course are their insidious presentations in older patients with various comorbidities, its disease extension at diagnosis, a lack of curative treatments and a certain therapeutic nihilism among the medical profession.

With surgical resection being reserved for a small minority of patients, the only intervention with proven impact on outcome is palliative chemotherapy. One trial randomly compared first line chemotherapy (either mitomycin, vinblastine, cisplatin (MVP) or vinorelbin) with active supportive care (ASC) [5]. Although no overall survival (OS) benefit or improvement in quality of life was seen in the intention-to-treat population, exploratory analyses suggested a survival advantage for vinorelbine with a 2 months' survival benefit over ASC that approached significance, although these benefits were not seen for those patients who received MVP. Two randomized trials have further set the standard of care to a combination of cisplatin with an antifolate, either pemetrexed or raltitrexed [6,7]. A complete analysis of the efficacy and cost-effectiveness of first-line chemotherapy in MPM showed that both schedules were not different in terms of response rate (RR), time-to-progression (TTP) and OS [8]. The implementation of novel first line chemotherapy has been associated with a population-based improvement in outcome over time [9].

With a median TTP of 5.5 months and $25 \%$ of patients refractory to first line chemotherapy, increasing numbers of patients are now likely to be candidate for second line treatment. A systematic review concluded in 2010 that no cytostatic, immunomodulating or targeted drug had been validated in second-line chemotherapy 
and patients in a good performance status should be recommended to enter clinical trials [10]. We updated this systematic review.

\section{Methods}

The search for prospective published trials relative to the second line treatment of malignant mesothelioma of pleural origin was performed by consulting the Medline and National Cancer Institute electronic databases. Search terms used included "mesothelioma" (medical subject heading $(\mathrm{MeSH})$ ) with the subheading "drug therapy," combined with "drug therapy" (MeSH), "chemotherapy" $(\mathrm{MeSH})$, and "antineoplastic agents" (MeSH), and the text words "mesothelioma" and "second line". Those terms were combined with the search terms for the following study designs and publication types: randomized controlled trials; controlled clinical trials; phase II or III clinical trials; and multicenter or comparative studies.

In addition, conference proceedings of the annual American Society of Clinical Oncology (ASCO), the annual European Society Medical Oncology (ESMO) and the bi-annual World Lung Cancer Conference (WCLC) meetings for the years 2010-2014 were searched for abstracts of relevant trials.

The criteria of eligibility of the articles were the following: to focus only on patients with MPM; to be related to the study of single or combined cytotoxic and/or targeted or biological agents, administered by systemic routes; to be published in the English language between January 2000 and July 2014; to be a prospective single or randomized phase II or phase III trial, with a minimum of 14 patients included. If less than 14 patients were included in a prospective phase II trial, the study could be considered as eligible if at least one objective response was observed when targeting a response rate of $20 \%$, according to the Gehan's design for phase II studies [11]. We assumed that a chemotherapeutic agent had a clinical potentially useful activity in a trial if its objective response rate was at least $20 \%$ and we considered that a study was negative if the upper limit of the $95 \%$ confidence interval (CI) of the response rate was $\leq 20 \%$. It was considered as positive if the lower limit of the $95 \% \mathrm{CI}$ was $>20 \%$ and as not conclusive but potentially positive if the upper limit of the $95 \%$ CI was $>20 \%$ but the lower limit $<20 \%$. For targeted and biological agents, we assumed that they had a clinical potentially useful activity if the reported disease control rate $(\mathrm{DCR}=$ rate of $\mathrm{OR}+$ stable disease $)$ was at least $50 \%$ and we considered that a study was negative if the upper limit of the $95 \% \mathrm{CI}$ of the response rate was $\leq 50 \%$. It was considered as positive if the lower limit of the $95 \% \mathrm{CI}$ was $>50 \%$ and as not conclusive but potentially positive if the upper limit of the $95 \% \mathrm{CI}$ was $>20 \%$ but the lower limit $<20 \%$.

Phase II trials with chemotherapy were grouped according to the following categories: single-agent chemotherapy, combination chemotherapy. Phase II trials with targeted and biological agents were grouped according to the predominant hallmark pathway involved: growth, angiogenesis, immunomodulation, invasion and metastasis, apoptosis [12].

The response rates of the non-comparative trials were summed and averaged by category.

\section{Results}

\subsection{Second-line chemotherapy in MPM}

We retrieved 86 articles matching the search criteria. Of these, 10 reported on phase II and phase III prospective clinical trials, of which one included less than 14 patients. Another 6 articles were found by cross referencing, of which 2 in overlaying patient groups, 2 included less than 14 patients, 1 included 15 patients, but with results of first- and second-line therapy. A total of 10 articles reporting on 1251 patients treated with second-line chemotherapy in MPM were eligible for this review (Table 1).

In an unplanned subgroup analysis of patients treated in the pivotal registration phase III trial, Manegold et al. reported a significantly prolonged survival in the patients treated with post-study chemotherapy [13]. Eighty-four patients (37.2\%) of the cisplatin and pemetrexed arm and 105 patients (47.3\%) from the cisplatin arm received post-study chemotherapy. The median time to start post-study chemotherapy after completion of first-line therapy was 3.6 months in the cisplatin/pemetrexed group and 0.7 months for the cisplatin group. According to that analysis, $62 \%$ of the study patients were treated with single agent post-study chemotherapy (48 from the pemetrexed/cisplatin group and 70 from the cisplatin group) and 38\% received combination chemotherapy (36 from the cisplatin/pemetrexed group and 35 from the cisplatin arm). Gemcitabine was mostly given as a single-agent. For patients with post-study chemotherapy, MST was 15.3 months in the cisplatin/pemetrexed group and 12.2 months for the cisplatin group. These figures set the stage as they suggest a potential benefit for second line treatment. Only patients with complete data were included in this analysis, leading to compare populations with small numbers reducing the statistical power of the analysis. It must nevertheless be emphasized that these data have important limitations due to a selection bias. Patients receiving second-line chemotherapy are indeed a selected group in good clinical condition that often benefited of previous treatments.

Pemetrexed is of interest due to its role as first-line therapy. The international Expanded Access Program (EAP) was opened before its commercial availability in 13 European countries and the US to provide both chemo-naïve and pre-treated patients access to pemetrexed, either as single agent therapy or in combination with platinum and this at the discretion of the investigator [14,15]. The results of EAP were reported in several publications, whereby results by treatment or treatment group were not always separately mentioned. In 396 pre-treated European patients, the overall response rate (ORR) with single agent pemetrexed was $12.1 \%$, and the median time to progression (TTP) 4.9 months [14]. The 1 -year survival rate was $47.2 \%$. Tolerability was good, suggested by the average amount of cycles of more than 6 . Hematological toxicity was mild. No separate data on patients treated with the combination are reported. One hundred and eighty seven previously treated US patients were included: 91 received pemetrexed monotherapy, 96 received cisplatin/pemetrexed combination therapy [15]. Previous regimens consisted of gemcitabine, cisplatin, carboplatin and paclitaxel. The patients receiving combination chemotherapy were on average younger and fitter at baseline and had a higher response rate to first-line therapy. This is also reflected by a higher number of treatment cycles administered to the combination group. Response data were available for 153 patients. ORR for the whole group was $19.6 \%$ with a RR of $32.5 \%$ for pemetrexed/cisplatin and $5.5 \%$ for pemetrexed alone. SD was achieved in $36.3 \%$ and $41.1 \%$ of patients, respectively. The median OS was 7.6 months with the combination therapy, 4.1 months with pemetrexed mono-therapy. Although the RR of 5.5\% in the pemetrexed alone group is low, it is comparable to other single-agent regimens, as reported in a systematic review [16]. In this series a selection bias is present, as patients with co-morbidities and lower performance status were included, who might otherwise have been assigned to the treatment with combination platinum/pemetrexed. Another bias constitutes the fact that inclusion criteria for an EAP are less stringent than for a formal clinical trial.

Sørensen et al. evaluated the efficacy of pemetrexed in second-line after platinum-based chemotherapy in 39 patients previously treated with platinum-based regimens without pemetrexed [17]. Twenty-eight Danish patients were treated with pemetrexed alone and 11 Norwegian patients with pemetrexed and 
Table 1

Studies in second line treatment of mesothelioma with chemotherapy single agents or combinations.

\begin{tabular}{|c|c|c|c|c|c|c|c|c|c|c|}
\hline $\begin{array}{l}\text { Trial characteristics } \\
\text { Number }\end{array}$ & $\begin{array}{l}\text { Chronological } \\
\text { order }\end{array}$ & 1 & 2 & 3 & 4 & 5 & 6 & 7 & 8 & 9 \\
\hline $\operatorname{REF}^{\circ}$ & cf. reference list & 23 & 22 & 19 & 21 & 18 & 17 & 14 & 15 & 20 \\
\hline Reference & Authors & Fazizi et al., JCO, 2003 & $\begin{array}{l}\text { Porta et al., Lung Cancer, } \\
2005\end{array}$ & $\begin{array}{l}\text { Stebbing et al., } \\
\text { Lung Cancer, } 2009\end{array}$ & $\begin{array}{l}\text { Tourkantonis et al., } \\
\text { Am. J. Clin. Oncol., } \\
2011\end{array}$ & $\begin{array}{l}\text { Jassem et al., J. Clin. } \\
\text { Oncol., } 2008\end{array}$ & $\begin{array}{l}\text { Sørensen et al., J. Thorac. } \\
\text { Oncol., } 2007\end{array}$ & $\begin{array}{l}\text { Taylor et al., J. Thorac. } \\
\text { Oncol., } 2008\end{array}$ & $\begin{array}{l}\text { Jänne et al., J. Thorac. } \\
\text { Oncol., } 2006\end{array}$ & $\begin{array}{l}\text { Giaccone et al., Eur. J. } \\
\text { Cancer, } 2008\end{array}$ \\
\hline Phase & II or III & $\begin{array}{l}\text { II, open-label, } \\
\text { non-comparative, } \\
\text { two-center }\end{array}$ & $\begin{array}{l}\text { II, 3-stage, } \\
\text { single-institution }\end{array}$ & $\begin{array}{l}\text { II, open-label, } \\
\text { non-comparative }\end{array}$ & $\begin{array}{l}\text { II, open-label, } \\
\text { single-arm, } \\
\text { single-center }\end{array}$ & $\begin{array}{l}\text { III, open-label, } \\
\text { randomized, } \\
\text { multicentre }\end{array}$ & $\begin{array}{l}\text { II, open-label, } \\
\text { non-randomized, } \\
\text { multicentre }\end{array}$ & $\begin{array}{l}\text { II, open-label, } \\
\text { non-randomized, } \\
\text { multicentre }\end{array}$ & $\begin{array}{l}\text { III, open-label, } \\
\text { non-randomized, } \\
\text { multicentre }\end{array}$ & $\begin{array}{l}\text { II, open-label, } \\
\text { non-comparative, } \\
\text { multicentre }\end{array}$ \\
\hline Category & $\begin{array}{l}\text { Single-agent } \\
\text { chemotherapy, } \\
\text { combination } \\
\text { chemotherapy, } \\
\text { growth, } \\
\text { angiogenesis, } \\
\text { immunomodula- } \\
\text { tion, invasion and } \\
\text { metastasis, } \\
\text { apoptosis }\end{array}$ & $\begin{array}{l}\text { Combination } \\
\text { chemotherapy }\end{array}$ & $\begin{array}{l}\text { Combination } \\
\text { chemotherapy }\end{array}$ & Single agent & & Single-agent & $\begin{array}{l}\text { Single-agent or } \\
\text { combination } \\
\text { chemotherapy }\end{array}$ & Single-agent & $\begin{array}{l}\text { Single-agent or } \\
\text { combination } \\
\text { chemotherapy }\end{array}$ & $\begin{array}{l}\text { Single-agent } \\
\text { chemotherapy }\end{array}$ \\
\hline $\begin{array}{l}\text { Agent } \\
\text { Regimen }\end{array}$ & $\begin{array}{l}\text { Generic name } \\
\text { Dosage and }\end{array}$ & & Raltitrexed & Vinorelbine & & Pemetrexed $500 \mathrm{mg} / \mathrm{m}^{2}$ & Pemetrexed $500 \mathrm{mg} / \mathrm{m}^{2}$ & Pemetrexed & & ZD0473 $120 \mathrm{mg} / \mathrm{m}^{2}$ or \\
\hline & $\begin{array}{l}\text { frequency of } \\
\text { administration }\end{array}$ & $\begin{array}{l}3 \mathrm{mg} / \mathrm{m}^{2}+\text { oxaliplatin } \\
130 \mathrm{mg} / \mathrm{m}^{2} \mathrm{q} 3 \mathrm{w}\end{array}$ & $\begin{array}{l}3 \mathrm{mg} / \mathrm{m}^{2}+\text { oxaliplatin } \\
130 \mathrm{~m} / \mathrm{m}^{2} \mathrm{q} 3 \mathrm{w}\end{array}$ & $30 \mathrm{mg} / \mathrm{m}^{2} \mathrm{q} 1 \mathrm{w}$ & $\begin{array}{l}1000 \mathrm{mg} / \mathrm{m}^{2}+ \\
\text { docetaxel } \\
80 \mathrm{mg} / \mathrm{m}^{2} \mathrm{q} 2 \mathrm{w}\end{array}$ & $\mathrm{q} 3 \mathrm{w}+\mathrm{BSC}$ versus BSC & $\begin{array}{l}\mathrm{q} 3 \mathrm{w} \text { or pemetrexed } \\
500 \mathrm{mg} / \mathrm{m}^{2}+\text { carboplatin } \\
\text { AUC } 5 \mathrm{q} 3 \mathrm{w}\end{array}$ & $500 \mathrm{mg} / \mathrm{m}^{2} \mathrm{q} 3 \mathrm{w}$ & $\begin{array}{l}\text { q3w or pemetrexed } \\
500 \mathrm{mg} / \mathrm{m}^{2}+\text { cisplatin } \\
75 \mathrm{mg} / \mathrm{m}^{2} \mathrm{q} 3 \mathrm{w}\end{array}$ & ZD0473 $150 \mathrm{~m} / \mathrm{m}^{2}$ \\
\hline Sample size & $N$ & 70 & 14 & 63 & 37 & 243 & 39 & 493 & 187 & 47 \\
\hline Patient characteristics & & & & & & & & & & \\
\hline Male (n) & $\mathrm{N}$ & 51 & 11 & 59 & 30 & 96 & 35 & 374 & 149 & 41 \\
\hline Male (\%) & $\%$ & 74 & 78.5 & 93.6 & 81.1 & 78 & 90 & 75.9 & 80 & 85 \\
\hline Age (median) & Number & 60 & 59.5 & 59 & 66 & 60 & 62 & 63 & 66 & 59 \\
\hline Age (range) & Numbers & $43-74$ & $42-71$ & 29-77 & $44-81$ & $32-78$ & $30-77$ & $31-85$ & $27-87$ & $37-75$ \\
\hline WHO PS $0-1$ & Number & 57 & 9 & 49 & 37 & 60 & 35 & 250 & n.a. & 36 \\
\hline WHO PS 0-1 & $\%$ & 81 & 64.2 & 77.8 & 100 & 48.8 & 90 & 64.5 & n.a. & 77 \\
\hline $\begin{array}{l}\text { Tumor characteristics } \\
\text { Epithelioid }\end{array}$ & & & & & & & & & & NR \\
\hline $\begin{array}{l}\text { Epithelioid } \\
\text { Epithelioid (\%) }\end{array}$ & $\begin{array}{l}N \\
\% \\
\end{array}$ & $\begin{array}{l}46 \\
66\end{array}$ & $\begin{array}{l}8 \\
57.1\end{array}$ & $\begin{array}{l}4.8 \\
62\end{array}$ & 73 & 73.2 & $\begin{array}{l}33 \\
85\end{array}$ & $\begin{array}{l}31.2 \\
71.2\end{array}$ & $\begin{array}{l}\text { n... } \\
\text { n.a. }\end{array}$ & $\mathrm{NR}$ \\
\hline First line treatment & $\begin{array}{l}\text { AFP, antifolate } \\
\text { platinum; D, } \\
\text { doxorubicin-based; } \\
\text { O, other }\end{array}$ & Cisplatin & $\begin{array}{l}\text { Doxorubicin + } \\
\text { rampirnase; } \\
\text { doxorubicin; } \\
\text { cisplatin + gemcitabine; } \\
\text { cisplatin + pemetrexed; } \\
\text { imatinib mesylate; mit- } \\
\text { omycin + methotrexate } \\
\text { + mitoxantrone; s.c. } \\
\text { interleukin- } \\
2+\text { interferon- } \alpha\end{array}$ & & $\begin{array}{l}\text { Carboplatin } \\
\text { + pemetrexed }\end{array}$ & & $\begin{array}{l}\text { Vinorelbine + cisplatin; } \\
\text { vinorel- } \\
\text { bine + carboplatin; } \\
\text { gemc- } \\
\text { itabine + carboplatin; } \\
\text { gemc- } \\
\text { itabine + caelyx + carboplatin }\end{array}$ & & $\begin{array}{l}\text { Gemcitabine; cisplatin; } \\
\text { carboplatin; paclitaxel; } \\
\text { navelbine; docetaxel; } \\
\text { doxorubicin }\end{array}$ & \\
\hline $\begin{array}{l}\text { Best response to 1st line } \\
\text { R/ }\end{array}$ & $\%$ & & PD & PR & & PD & & & PR & \\
\hline $\begin{array}{l}\text { Treatment characteristics } \\
\text { Response criteria }\end{array}$ & $\begin{array}{l}\text { RECIST 1.0; RECIST } \\
1.1 \text {; modified } \\
\text { RECIST }\end{array}$ & $\mathrm{NA}$ & RECIST 1.0 & RECIST 1.0 & NS & & Modified RECIST & RECIST, SWOG, WHO & RECIST & RECIST \\
\hline $\begin{array}{l}\text { Number of responses to } \\
\text { 2nd line }\end{array}$ & $N$ & 3 & 0 & 10 & 7 & & & 48 & 30 & \\
\hline ORR (\%) to 2nd line & $\%$ & 20 & & 16 & & 18.7 & & 12.1 & 19.6 & 0 \\
\hline $\begin{array}{l}\text { Number of SD to 2nd } \\
\text { line }\end{array}$ & $N$ & & 4 & 43 & 23 & 50 & & 182 & 59 & 0 \\
\hline SD rate (\%) to 2 nd line & $\%$ & & 28.6 & 68 & & 40.7 & & 46 & 38.6 & 66 \\
\hline DCR to 2nd line & $\%$ & & & 84 & & 59.3 & & 58.1 & 58.2 & \\
\hline $\begin{array}{l}\text { Median PFS } \\
\text { PFS @ } 1 \text { year }\end{array}$ & $\begin{array}{l}\text { Months } \\
\%\end{array}$ & 6.2 & 2 & & 7 & 3.6 & 6.1 & 4.9 & & 2.5 \\
\hline $\begin{array}{l}\text { PFS @ 1 year } \\
\text { Median OS } \\
\text { OS @ } 1 \text { year }\end{array}$ & $\begin{array}{l}\% \\
\text { Months } \\
\%\end{array}$ & $\begin{array}{l}10.1 \\
40\end{array}$ & 3.5 & 9.6 & 16.2 & 8.4 & 36 & $\begin{array}{l}9.5 \\
47.2\end{array}$ & & 6.8 \\
\hline $\begin{array}{l}\text { Toxicity } \\
\text { Grade 3-4 hematotox }\end{array}$ & N & & $\begin{array}{l}\text { 21\% hematox; } 7 \% \text { GI tox; } \\
\text { 7\% neurotox; }\end{array}$ & $\begin{array}{l}72 \% \text { hematox; } 11 \% \\
\text { Gl tox; } 8 \% \text { neurotox }\end{array}$ & $\begin{array}{l}46 \% \text { hematox; } 11 \% \\
\text { GI tox; } 8 \% \\
\text { neurotox; } 5 \% \\
\text { respiratory tox }\end{array}$ & $\begin{array}{l}11 \% \text { hematox; } 9 \% \mathrm{GI} \mathrm{tox} ; \\
18 \% \text { respiratory tox }\end{array}$ & & $18 \%$ hematox & & $43 \%$ respiratory tox \\
\hline
\end{tabular}


carboplatin. Treatment with pemetrexed monotherapy gave a RR of $21 \%$ with a median TTP 4.9 months (range 4-92) and OS 9.8 months (4-99 weeks), 1-year survival rate was $36 \%$. In the pemetrexed/carboplatin group the RR was $18 \%$, the median TTP 7.4 months and OS 9.1 months. The authors conclude that second line treatment with single agent pemetrexed as in pemetrexed naive patients, is justified.

A large multicentre phase III study in advanced mesothelioma was designed to compare the efficacy and safety of pemetrexed and best supportive care (BSC) [18]. Patients with relapsed MPM after first-line chemotherapy (excluding pemetrexed) were randomized between pemetrexed $500 \mathrm{mg} / \mathrm{m}^{2}$ every 21 days or BSC alone. Treatment was given for eight cycles or until progressive disease (PD). The primary endpoint of the study was OS. Secondary endpoints included RR, TTP, progression free survival (PFS), time to treatment failure and toxicity. Of the 243 patients included, the 143 patients receiving pemetrexed showed a PR in $18.7 \%$. RR was $19.2 \%$ with pemetrexed versus $1.7 \%$ in the BSC arm, respectively. The median TTP was 3.8 months versus 1.5 months. The median OS was not significantly different with 8.6 months versus 9.8 months, maybe due to the significant imbalance in post-study chemotherapy between the arms. This phase III trial demonstrated that pemetrexed in second-line delays disease progression for advanced MPM, reflected by the DCR of almost $60 \%$ in the pemetrexed arm and $19.2 \%$ in BSC arm. The chemotherapy was well tolerated and toxicities were mild. The BSC arm had a disproportionate number of patients who discontinued the study before response evaluation compared to the pemetrexed plus BSC arm. After study-discontinuation chemotherapy was allowed. Significantly more patients in the BSC arm (51.7\%) received post-discontinuation chemotherapy than in the experimental arm (28.5\%). Platinum, pemetrexed and gemcitabine were the most commonly used agents.

In a phase II, open-label single-agent trial, the safety and efficacy of weekly vinorelbine was assessed [19]. Patients with a good performance status and prognostic score according to EORTC were included. Sixteen percent of 63 pre-treated patients had a partial response to vinorelbine. Forty-three patients (68\%) had a SD defined as no evidence for progression for 6 months. The OS was 9.6 months. Over half of the patients experienced a grade 3/4 toxicity. Median interval between the end of first-line chemotherapy and the start of weekly vinorelbine was 6 months. No separate analysis was performed in the patients pre-treated with pemetrexed.

Picoplatin was designed to overcome resistance mechanisms. A phase II, open-label, non-comparative, multicentre study was designed to evaluate the activity and tolerability of picoplatin in 47 MPM pre-treated patients [20]. The majority had advanced disease and $83 \%$ received prior platinum-based therapy. Of 43 evaluable patients no CR or PR was observed. This resulted in a RR of $12 \%$ of patients with a minor response, defined by reduction of lesion size $\geq 10 \%$ but $<50 \%$. SD was seen in $44 \%$. The median TTP was 2.5 months, OS was 6.7 months. Picoplatin demonstrated a manageable tolerability profile. However, no complete or partial responses were seen. The activity of picoplatin is comparable to cisplatin in first-line therapy and warrants no further investigation in MPM.

The combination gemcitabine and docetaxel was evaluated in 37 pre-treated patients [21]. Docetaxel $80 \mathrm{mg} / \mathrm{m}^{2}$ and gemcitabine $1000 \mathrm{mg} / \mathrm{m}^{2}$ were given on day 1 and 14 of a 28-day cycle. Support of granulocyte colony-stimulating factor was allowed. The primary endpoint was RR and the secondary endpoints included TTP and OS. In 7 patients (18.9\%) a PR was seen, SD in 23 patients (62.2\%) and PD in 7 patients (18.9\%). The median TTP was 7 months (range $5.8-8.2$ months) with a median survival of 16.2 months (range 13-19.3 months). Haematologic toxicity occurred mostly with grade 3-4 neutropenia. However, the combination of gemcitabine and docetaxel is tolerable and safe and can be an option in pre-treated patients.

The combination of raltitrexed and oxaliplatin was investigated in 2 studies. Porta reported results of 14 patients who were treated with raltitrexed/oxaliplatin [22]. In this group, prior treatment mainly consisted of cisplatin and doxorubicin. No objective responses were seen and disease stabilization was observed in 4 patients. The 10 other patients were progressing, with a median time to progression of 1.9 months. The median OS was 6.7 months. Although the combination of raltitrexed/oxaliplatin has RRs in treatment naive patients of 30-35\%, it failed to show any significant activity in second-line treatment of MPM.

Fizazi et al. performed an open-label, non-comparative, multicentre, phase II trial of 15 pre-treated patients and 55 chemo-naïve MPM [23]. All pre-treated patients had prior cisplatin and a minimum of 2 chemotherapy regimens and were treated with raltitrexed/oxaliplatin. The RR was 20\%, the median TTP 6.2 months, and the median OS 10.1 months. The combination showed responses even in the cisplatin-resistant patients. The one-year OS was $40 \%$. The toxicity was manageable; the most reported toxicity was asthenia. Grade 3 anemia and neutropenia were observed only in $4.1 \%$ and $6.9 \%$ of the patients, respectively.

In vitro data suggest that valproic acid, a histone deacetylase inhibitor (HDACi), has a pro-apoptotic effect and synergised with doxorubicin to induce apoptosis in malignant mesothelioma cells [24]. In a phase II trial, 45 patients pre-treated with at least one chemotherapy regimen including platinum derivatives, regardless response, received the combination of valproic acid and doxorubicin [25]. The RR was $16 \%$. The median PFS and the median OS was 2.5 months and 6.7 months, respectively. Two deaths were related to toxicity, both in patients with poor PS. The authors commented that this combination seems to be an effective second-line treatment in patients with good PS.

\subsection{Second line targeted and biological agents}

As an alternative to a cytotoxic treatment, researchers have tested inhibitors of other hallmarks pathways in MPM, from oral tyrosine kinase inhibitors over epigenetic compounds to immunotherapy (see Table 2).

\subsection{Genetics}

Recently, somatic and germ line genetic alterations have been identified that may lead to MPM itself or increase the susceptibility to asbestos carcinogenesis. MPM is particularly characterized by the loss of tumor suppressor genes, rather than gain of function mutations. The most frequently mutated tumor suppressor genes are discussed here and their possible implications for therapeutic interventions [26].

Mutations in the neurofibromatosis type 2 gene (NF2) are found in $35-40 \%$ of MPM. The NF2 gene encodes a tumor suppressor gene merlin, a member of the band 4.1 family of cytoskeletal linker proteins. When the NF2 gene is mutated, non-functional versions of merlin will be produced, being unable to function properly. Merlin mediates the contact dependent inhibition of cell proliferation in normal cells and interacts with more than 30 other intracellular proteins. Together with Focal Adhesion Kinase (FAK) it also inhibits the growth of cancer stem cells. Other key pathways are the mammalian target of rapamycin (mTOR); the Hippo pathway, which is important in cell proliferation, and extracellular signal-regulated kinase (ERK) pathways [26,27].

mTOR activity is up regulated in the absence of merlin, leading to increased cell proliferation. In the SWOG 0722 phase 2 trial the mTOR inhibitor everolimus was tested in 2 nd or $3 \mathrm{rd}$ line. It did not meet its primary endpoint, an improvement of 4 months in PFS from 
Table 2

Studies in second line treatment of mesothelioma with targeted agents or immunomodulating drugs.

\begin{tabular}{|c|c|c|c|c|c|c|c|c|c|}
\hline \multicolumn{10}{|l|}{ TKI } \\
\hline Number & $\begin{array}{l}\text { Chronological } \\
\text { order }\end{array}$ & 1 & 2 & 3 & 4 & 5 & 6 & 7 & 8 \\
\hline $\operatorname{REF}^{\circ}$ & cf. reference list & 28 & 33 & 39 & 40 & 41 & 42 & 43 & 44 \\
\hline Reference & Authors & $\begin{array}{l}\text { SWOG 0722, } \\
\text { Garland ea, ASCO } \\
\text { annual meting }\end{array}$ & $\begin{array}{l}\text { VANTAGE-014, } \\
\text { Krug et al., Lancet } \\
\text { Oncology }\end{array}$ & $\begin{array}{l}\text { Kindler et al.. } \\
\text { Journal of Clinical } \\
\text { Oncology }\end{array}$ & $\begin{array}{l}\text { CALGB 30307, } \\
\text { Dubey et al., JTO }\end{array}$ & $\begin{array}{l}\text { NCIC, Laurie et al., } \\
\text { JTO }\end{array}$ & $\begin{array}{l}\text { CALGB 30107, } \\
\text { Jahan et al., Lung } \\
\text { Cancer }\end{array}$ & $\begin{array}{l}\text { University of } \\
\text { Chicago phase II } \\
\text { consortium, } \\
\text { Campbell et al., } \\
\text { Lung Cancer }\end{array}$ & $\begin{array}{l}\text { SWOG S0509, } \\
\text { Garland, JTO }\end{array}$ \\
\hline Phase & II or III & II & III & II (randomized) & II & II & II & & II \\
\hline Agent & Generic name & Everolimus & Vorinostat & Bevacizumab & Sorafenib & Sunitinib & Vatalanib & Cediranib & Cediranib \\
\hline Regimen & $\begin{array}{l}\text { Dosage and } \\
\text { frequency of } \\
\text { administration }\end{array}$ & Daily oral $1 \times 10 \mathrm{mg}$ & $\begin{array}{l}\text { Oral } 2 \times 300 \mathrm{mg}, 3 \\
\text { days/week vs } \\
\text { placebo }\end{array}$ & $\begin{array}{l}\text { Gemcitabin/cislatin } \\
\text { q3w } \pm \text { bevacizumab } \\
15 \mathrm{mg} / \mathrm{kg}\end{array}$ & $\begin{array}{l}\text { Daily oral } 2 \times \\
400 \mathrm{mg}\end{array}$ & $\begin{array}{l}\text { Daily oral } 1 \times 50 \mathrm{mg} \\
4 \mathrm{w}, 2 \mathrm{w} \text { rest }\end{array}$ & $\begin{array}{l}\text { Daily oral } 1 \times \\
1250 \mathrm{mg}\end{array}$ & $\begin{array}{l}\text { Daily oral } 1 \times 45 \\
\text { and } 1 \times 30 \mathrm{mg}\end{array}$ & Daily oral $1 \times 45 \mathrm{mg}$ \\
\hline Sample size & $N$ & 57 & 661 & 108 & 50 & 17 & 47 & 50 & 47 \\
\hline \multicolumn{10}{|l|}{ Patient characteristics } \\
\hline Male (n) & N & 43 & $283 / 270$ & $39 / 46$ & 35 & 14 & 43 & 42 & 38 \\
\hline Male (\%) & $\%$ & 75 & $86 / 81$ & $74 / 84$ & 70 & 82 & 90 & 84 & 81 \\
\hline \multicolumn{10}{|l|}{ Tumor characteristics } \\
\hline Epithelioid & N & n.a. & $274 / 269$ & $39 / 37$ & 37 & 10 & 36 & 36 & 28 \\
\hline Epithelioid (\%) & $\%$ & 61 & $83 / 81$ & $74 / 67$ & 74 & 59 & 77 & 72 & 60 \\
\hline Best response to 1 st line $\mathrm{R} /$ & $\%$ & n.a. & n.a. & n.a. & n.a. & n.a. & n.a. & n.a. & n.a. \\
\hline \multicolumn{10}{|l|}{ Treatment characteristics } \\
\hline Remark & & $\begin{array}{l}\text { Did not reach } \\
\text { primary endpoint }\end{array}$ & & $\begin{array}{l}\text { Higher } \\
\text { pretreatment } \\
\text { plasma VEGF } \\
\text { associated with } \\
\text { shorter PFS }\end{array}$ & & & & $\begin{array}{l}\text { Dose was lowered } \\
\text { after } 15 \text { patients to } \\
30 \text { mg due to } \\
\text { toxicity }\end{array}$ & $\begin{array}{l}2 \text { patients had } 91 \% \\
\text { and } 56 \% \text { tumor } \\
\text { shrinkage }\end{array}$ \\
\hline ORR (\%) to 2nd line & $\%$ & - & $1 /<1$ & $25 / 22$ & 6 & 0 & 6 & 10 & 9 \\
\hline SD rate (\%) to 2nd line & $\%$ & - & n.a. & $51 / 60$ & 54 & & 72 & 34 & 34 \\
\hline PFS @ 1 year & $\%$ & & n.a. & Median 6.9/6.0 mo & Median PFS 3.6 mo & Median PFS 2.8 mo & Median PFS $4.1 \mathrm{mo}$ & Median PFS $1.8 \mathrm{mo}$ & Median PFS 2.6 mo \\
\hline Median OS & Months & $5 \mathrm{mo}$ & $8 \mathrm{mo} \mathrm{vs} 7 \mathrm{mo}$ & $15.6 \mathrm{mo}$ vs $14.7 \mathrm{mo}$ & $9.7 \mathrm{mo}$ & $8.3 \mathrm{mo}$ & $10.0 \mathrm{mo}$ & $4.4 \mathrm{mo}$ & $9.5 \mathrm{mo}$ \\
\hline \multicolumn{10}{|l|}{ Toxicity } \\
\hline Grade 3-4 & N & n.a. & $\begin{array}{l}16 \text { vs } 8 \% \text { fatigue; } 11 \\
\text { vs } 14 \% \text { dyspnea }\end{array}$ & $26.4 / 14.6$ & $\begin{array}{l}24 \% \text { fatique, } 12 \% \\
\text { rash, } 8 \% \text { dyspnea }\end{array}$ & $\begin{array}{l}29 \% \text { fatique, } 12 \% \mathrm{GI} \text {, } \\
5 \% \text { hand-foot }\end{array}$ & $\begin{array}{l}15 \% \text { nausea, } 11 \% \\
\text { elevated ALAT }\end{array}$ & $\begin{array}{l}87 \% \text { in } 45 \mathrm{mg} \\
\text { group, } 43 \% \text { in } \\
30 \mathrm{mg} \text { group }\end{array}$ & $\begin{array}{l}64 \% \text { fatique, } 64 \% \\
\text { diarrhea, } 70 \% \\
\text { hypertension }\end{array}$ \\
\hline Grade 5 toxicity & $\begin{array}{l}N \\
\%\end{array}$ & $\begin{array}{l}1 \\
2\end{array}$ & $1 / 0$ & n.a. & $\begin{array}{l}0 \\
0\end{array}$ & $\begin{array}{l}0 \\
0\end{array}$ & $\begin{array}{l}0 \\
0\end{array}$ & $\begin{array}{l}0 \\
0\end{array}$ & $\begin{array}{l}0 \\
0\end{array}$ \\
\hline \multirow{2}{*}{\multicolumn{10}{|c|}{$\begin{array}{l}\text { TKI } \\
\text { Trial characteristics }\end{array}$}} \\
\hline \multicolumn{5}{|l|}{ Trial characteristics } & & & & & \\
\hline Number & 9 & 10 & 11 & 12 & 13 & 14 & 15 & 16 & 17 \\
\hline $\operatorname{REF}^{\circ}$ & 45 & 46 & 52 & 53 & 49 & 50 & 48 & 47 & 61 \\
\hline Reference & Nowak et al., JTO & $\begin{array}{l}\text { NVALT 5, } \\
\text { Buikhuisen et al., } \\
\text { Lancet Oncology }\end{array}$ & $\begin{array}{l}\text { SWOG, Garland } \\
\text { et al., JCO }\end{array}$ & $\begin{array}{l}\text { Jackman et al., } \\
\text { Cancer }\end{array}$ & $\begin{array}{l}\text { Mathy et al., Lung } \\
\text { Cancer }\end{array}$ & $\begin{array}{l}\text { CALGB 30601, } \\
\text { Dudek, JTO }\end{array}$ & $\begin{array}{l}\text { Nowak et al., Lung } \\
\text { Cancer }\end{array}$ & Gregorc et al., Jco & $\begin{array}{l}\text { ICORG 05-10, Fennell } \\
\text { et al., JTO }\end{array}$ \\
\hline Phase & II & III randomized & II & II & II & II & II & II & II \\
\hline Agent & Sunitinib & Thalidomide & Erlotinib & $\begin{array}{l}\text { Erlotinib } \\
\text { bevacizumab }\end{array}$ & Imatinib & Dasatinib & BNC 105P & NGR-hTNF & Bortezomib \\
\hline Regimen & $\begin{array}{l}\text { Daily oral } 50 \mathrm{mg} \\
4 \mathrm{w}, 2 \mathrm{w} \text { rest }\end{array}$ & $\begin{array}{l}\text { Daily oral } \\
200 \mathrm{mg} / \text { active } \\
\text { supportive care }\end{array}$ & $\begin{array}{l}\text { Daily oral } 1 \times \\
150 \mathrm{mg}\end{array}$ & $\begin{array}{l}\text { Daily oral erlotinib } \\
1 \times 150 \mathrm{mg} \\
\text { bevacizumab } \\
15 \mathrm{mg} / \mathrm{kg} \text { iv d1 q21 }\end{array}$ & $\begin{array}{l}\text { Daily oral } \\
400-800 \mathrm{mg}\end{array}$ & $\begin{array}{l}\text { Daily oral } 2 \times \\
70 \mathrm{mg} \text {, after } 23 \text { pts } \\
2 \times 50 \mathrm{mg} \text { due to } \\
\text { toxicity }\end{array}$ & $\begin{array}{l}16 \mathrm{mg} / \mathrm{m}^{2} \text { iv d1 } 8 \\
\text { q21d }\end{array}$ & $\begin{array}{l}0.8 \mu \mathrm{g} / \mathrm{m}^{2} \text { iv } \mathrm{q} \\
21 \mathrm{~d} / \text { and } \mathrm{q} 7 \mathrm{~d}\end{array}$ & $\begin{array}{l}1.6 \mathrm{mg} / \mathrm{m}^{2} \text { iv d1 }, 8,15 \\
22 \mathrm{q} 35 \mathrm{~d}\end{array}$ \\
\hline Sample size & 51 & 222 & 61 & 24 & 25 & 43 & 30 & $43 / 14$ & 21 \\
\hline \multirow{2}{*}{\multicolumn{10}{|c|}{ Patient characteristics }} \\
\hline & & & & & 80 & 31 & 27 & $27 / 8$ & 20 \\
\hline Male (\%) & $83 \%$ & $83 / 86$ & 75 & 62 & 20 & 72 & 90 & $63 / 57$ & 87 \\
\hline \multicolumn{10}{|l|}{ Tumor characteristics } \\
\hline $\begin{array}{l}\text { Epithelioid } \\
\text { Enithelioid (\%) }\end{array}$ & 39 & $95 / 94$ & ${ }_{44}^{28}$ & 16 & $\begin{array}{l}20 \\
80\end{array}$ & 33 & 20 & $34 / 11$ & 16 \\
\hline Epithelioid (\%) & 73 & 86/85 & 44 & 67 & 80 & 77 & 67 & 79/79 & 70 \\
\hline Best response to 1 st line $\mathrm{R} /$ & n.a. & No PD & n.a. & n.a. & n.a. & n.a. & n.a. & PR 12/14 SD 56/57 & n.a. \\
\hline $\begin{array}{l}\text { Treatment characteristics } \\
\text { Response criteria } \\
\text { Remark }\end{array}$ & $\begin{array}{l}\text { Study was unable } \\
\text { to find biomarkers } \\
\text { of response }\end{array}$ & + & $\begin{array}{l}+ \\
33 \text { patients had } \\
\text { measurable disease }\end{array}$ & + & - & + & + & $\begin{array}{l}+ \\
\text { Weekly NGR-hTNF } \\
\text { warrant additional } \\
\text { evaluation }\end{array}$ & + \\
\hline
\end{tabular}




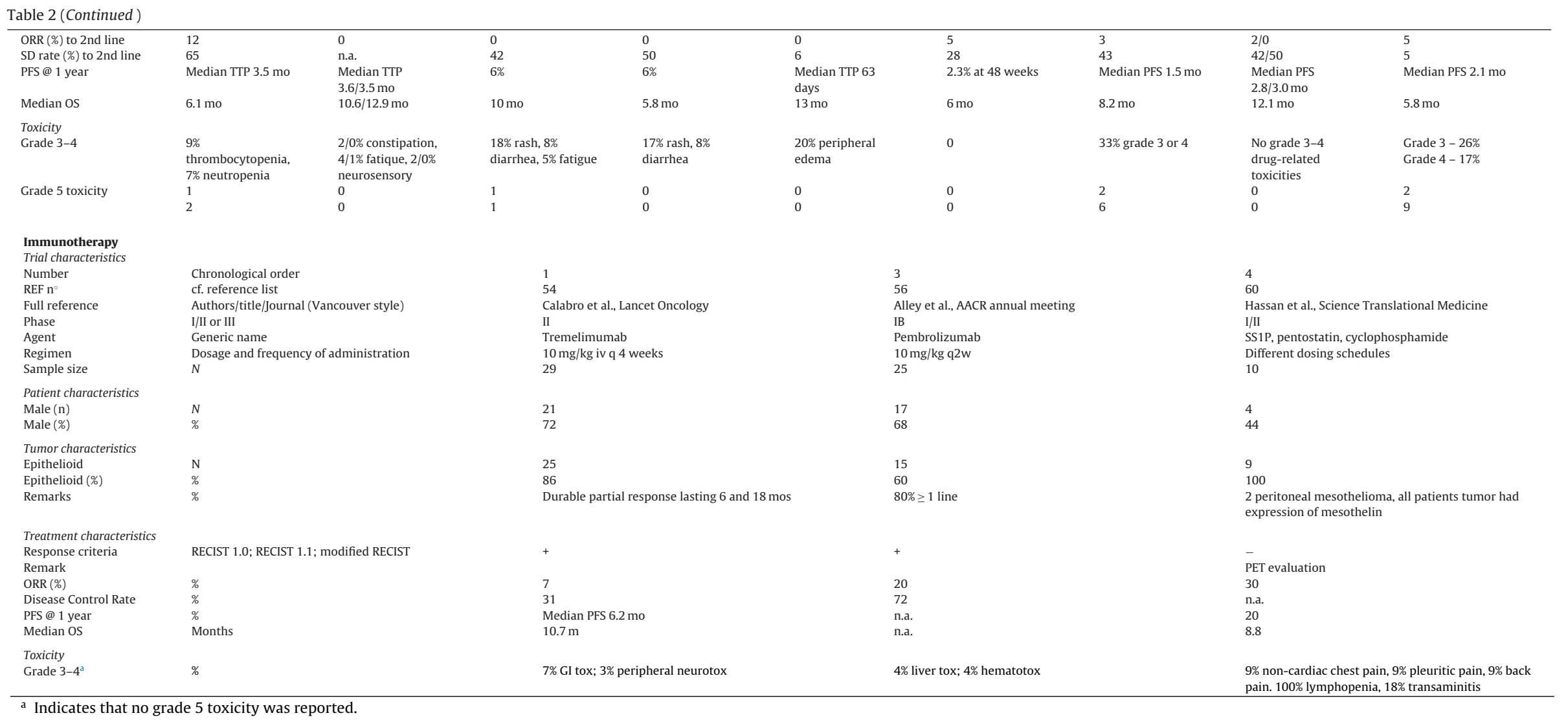

Indicates that no grade 5 toxicity was reported. 
30\% to 50\% (4 months PFS 34\%) [28]. In view of the compensatory up regulation of PI3K seen with mTOR inhibition alone, dual inhibition of both mTOR and PI3K, maybe a better approach. This was tested in a phase 1 study in patients with mesothelioma. An expansion cohort was created with the dual PI3K and mTOR inhibitor GDC0980 with encouraging results [29].

Further exploration of the mTOR signaling pathway involves focal adhesion kinase (FAK). This enzyme is involved in cell migration, adhesion and invasion. Merlin, the protein encoded by NF2, blocks FAK activation, so there is higher activation of FAK in tumors with merlin loss. VS-6063 is an inhibitor of FAK and appears to block the growth of mesothelioma cells in both xenografts and cell lines. This drug appears to work best in merlin deficient cell lines, but there still are signs of inhibition in wild type mesothelioma cell lines [30]. These preclinical data led to the randomized phase 2 maintenance study of VS6063 that is ongoing (NCT01870609), the estimated study completion date is December 2016. Primary endpoint will be PFS and OS.

BRCA1-associated protein-1 (BAP1) is inactivated in at least a quarter of MPM, although a number of different mutations have been identified [31]. BAP1 has a role in DNA repair, control of gene expression through histone modification and enhancing progression through the G1-S checkpoint [32]. The role of BAP1 in histone modification is of interest since it raises the possibility that histone deacetylase inhibitors (HDAC) may have activity in the disease. However the lack of clinical response in a large randomized phase 3 trial of the HDAC inhibitor vorinostat deny HDAC inhibitors to be an important strategy in tumors with BAP1 loss [33].

\subsection{Vascular targeted drugs}

Tumor growth is strongly dependent upon angiogenesis and newly formed feeding vessels are required when the tumor size exceeds a diameter of $2 \mathrm{~mm}$ [34]. Mesothelioma cells often express vascular endothelial growth factor receptors (VEGFR) and produce growth factors like VEGF and basic fibroblast growth factor (bFGF) [35]. Patients with MPM express serum VEGF levels that are higher compared to other solid tumors or healthy individuals [36]. High serum levels of VEGF and bFGF and microvessel density have been identified as negative prognostic factors for MPM [37,38].

For these reasons many studies using anti-angiogenic treatments in malignant mesothelioma have been published, but mostly with disappointing results. In a randomized phase II study investigating the effect of bevacizumab, a VEGF monoclonal antibody, in patients receiving cisplatin and gemcitabine, bevacizumab did not improve outcome [39]. Although in this study an exploratory subset analysis showed improved survival for the bevacizumab chemotherapy regimen in patients with low circulating levels of VEGF. Other phase II studies tested drugs with anti angiogenic properties like sorafenib [40], sunitinib [41], vatalanib [42] and cediranib [43], all of which reported low response rates and failed to show any anti tumor activity. One phase II study showed modest activity of cediranib after previous platinum-based therapy. Four patients (9\%) in this single arm study showed a partial response, which did not meet the pre-specified $20 \%$ response rate of interest. However, there was marked shrinkage of bulky tumors in two of the four patient responders [44]. This was the reason to proceed with a larger randomized phase II trials testing cediranib in combination with pemetrexed and cisplatin. A second phase II study of sunitinib as second-line therapy reported modest activity in progressing patients, but was unable to identify any serum biomarkers of response in angiogenesis pathways [45]. A large randomized phase III study examined the oral antiangiogenic drug thalidomide in a switch maintenance setting. Patients with malignant mesothelioma who did not show progression after first line chemotherapy were randomized to receive thalidomide or active supportive care until progression. The addition of thalidomide did not show any benefit in time to progression or overall survival [46].

\subsection{Immunomodulation and other pathways}

The vascular disrupting agent NGR-hTNF is a combination of tumor necrosis factor (TNF), regulator of immune cells and inhibitor of tumourigenesis and asparagines-glycine-arginine (NGR). It selectively targets TNF to an aminopeptidase N/CD13 isoform overexpressed by endothelial cells in solid tumors. A single agent phase 2 trial in 57 pretreated MPM patients showed a disease control rate of $46 \%$, these patients experienced a median progressionfree time of 4.4 months [47]. These results lead to a randomized phase 2 study NGR015 in which pemetrexed pretreated patients receive second line chemotherapy vinorelbin or doxorubicin combined with either NGR-hTNF or placebo. The trial has completed its accrual and results are awaited (NCT01098266). Another incomplete study with NGR-hTNF is the randomized phase 2 trial NGR 019, with either weekly maintenance NGR-hTNF or placebo in patients not progressing after 6 cycles of pemetrexed containing therapy (NCT01358084).

BNC105P is a tubulin polymerization inhibitor that selectively disrupts tumor vasculature and suppresses cancer cell proliferation. In a second line phase 2 study BNC105P was given until progression. Results were disappointing with a median PFS of 1.5 months. These results did not warrant further research as a single agent [48].

Platelet derived growth factor (PDGF) is a growth factor inducing mesothelial cell proliferation through the cell membrane receptor platelet derived growth factor receptor (PDGFR). A high serum PDGF in patients with MPM is an independent factor of poor prognosis. Imatinib and dasatinib are TKI inhibiting the PDGFR, but did not show clinical activity as single agents in phase II studies [49,50].

EGFR plays a role in cell proliferation, differentiation, migration, adhesion and survival. EGFR is overexpressed at protein level in more than $50-95 \%$ of the patients. Activating driver mutations of the tyrosine kinase residue, which translates the signal downstream and makes the tumor addicted to growth are rare in MPM [51]. The EGFR TKI erlotinib and the combination of erlotinib and the chimeric mouse-human antibody targeting the extracellular domain of EGFR, cetuximab were studied in 2 phase 2 studies. Results were disappointing with no patients achieving a partial response [52,53].

The anti-cytotoxic T lymphocyte antigen 4 (CTLA4) specific monoclonal antibody tremelimumab is a new class of immunomodulatory monoclonal antibody. It targets the regulatory molecules expressed on immune cells to enhance the anti-tumor activity of T-cells. In a single arm phase 2 study, twenty-nine patients were enrolled with unresectable MPM with progressive disease after first-line platinum-based regimen [54]. Although the study did not meet its primary endpoint, it did show encouraging clinical activity. Disease control was observed in 9 patients (31\%) with a median progression free survival of 6.2 months and median overall survival of 10.7 months. Two patients (7\%) had durable partial responses, respectively 6 and 18 months. Another phase 2 study in which also 29 patients were treated with tremelimumab $10 \mathrm{mg} / \mathrm{kg}$ every 4 weeks showed similar results [55]. A randomized, double blind, placebo controlled, phase 2 study is currently evaluating tremelimumab with the primary objective of demonstrating a 50\% improvement in overall survival from 7 to 10.5 months (NCT01843374). After a recent interim analysis the accrual target was increased to 542 patients.

A checkpoint inhibitor, pembrolizumab, was tested as single agent in a phase I/II study and reported in abstract [56]. In 25 patients out of 38 patients with positive staining for PD-L1, pembrolizumab treatment $(10 \mathrm{mg} / \mathrm{kg} \mathrm{q} 2 \mathrm{wk}$ ) resulted in a ORR of $20 \%$ 
and $72 \%$ had control of the disease. Ten patients could be treated for over 9 months with low toxicity. Only 1 grade 3 toxicity for ALT and 1 for thrombocytopenia were observed. These results have lead to a randomized phase II study (NCT02399371) currently open for recruitment in second line.

Mesothelin is an antigen, which is highly expressed on certain tumor cells like mesothelioma, ovarian and pancreatic carcinoma. In normal tissues its expression is limited to mesothelial cells lining the pleura, the peritoneum and pericardium [57,58]. Mesothelin has been used to target MPM in different ways. SS1P is a recombinant immunotoxin consisting of an anti-mesothelin variable fragment linked to PE38, a portion of Pseudomonas exotoxin A. In the preclinical setting it has shown to be cytotoxic to mesothelin expressing cell lines [59]. In the first clinical trials, the vast majority of treated patients developed antibodies against SS1P after only one cycle of treatment, precluding its continued use as a therapeutic agent. To overcome this problem, patients were pretreated with pentostatin and cyclophosfamide; chemotherapeutic agents that specifically deplete lymphocytes, thereby preventing the formation of antitoxin antibodies. This resulted in remarkable improved clinical outcomes. Of 10 patients with chemotherapy-refractory mesothelioma, 3 had a major tumor regression, with 2 ongoing at 15 months, and to respond to chemotherapy after discontinuing immunotoxin therapy in an unexpected way [60]. The development of anti-pseudomonas antibodies have urged the researchers to develop a second-generation immunotoxin where the B-cell activating sites of the molecule have been replaced by less immunogenic residues.

Bortezomib, a proteasome inhibitor, was tested as single agent in a multicenter study. Of the 23 patients included, only 1 patient responded (4.8\%). The PFS was 2.1 month with an OS of 5.8 months [61]. Single agent therapy showed insufficient activity to continue research in unselected patients.

\section{Conclusions}

The development of effective treatments in MPM has been notoriously slow and unsuccessful. It was until 2003 when two randomized phase III studies showed that the combination of a platin compound and anti-folate improved PFS, OS and did not impair the quality of life. Unfortunately the disease recurred in over $80 \%$ of the patients at the 2-year follow up mark. This leads to new studies in MPM in the second line setting. The classical, chemotherapy compounds tested, did not really show any improvement and more emphasis was given to drugs that might stabilize the disease with manageable toxicity. Only one phase III study was reported where pemetrexed was compared to BSC. The final analysis did not show any benefit in OS but an improvement in disease control was observed. Crossover from the BSC arm to pemetrexed probably accounts for this observation. Other single agent drugs did not impress the scientific community with activity or tolerability.

Only a limited number of randomized phase II studies with combination therapy have been examined. They focused mostly on a combination with pemetrexed and platin compound. Although acceptable in patients with a good PS, none of these have been adopted as standard therapy in second line.

The following conclusions regarding second line chemotherapy in MPM can be drawn:

- Single agent vinorelbine or pemetrexed are acceptable 2nd line agents for patients relapsing after a first line platinum combination depending on its association with pemetrexed or not.

- The low reported activity of the drugs in second line warrants referral of fit patients to participate in clinical trials [11]. The latter should preferably consist of randomized phase 2 trials, whereby patients will be randomly allocated to either the new single agent or one of the single agents with documented activity.

With the identification of driver mutations in lung cancer, high expectations were also set for mesothelioma. Unfortunately the TKI's did not perform as expected. While high levels of EGFR expression were observed in most MPM samples, no mutations in exon 19 of deletion in exon 21 were observed. Pathways of interest in MPM have been narrowed down to MTOR and PI3CA, while others have been tested without a clear success. New approaches like the use of immune checkpoint inhibitors and immunotoxins seem to be more effective. Studies in maintenance setting or in second or third line are now in place and seem to be very active in a subset of patients. The problem remains how to select patients suitable for this kind of therapy.

It is clear that the new developments in immunotherapy and pathway modulation will open new perspectives for treatment. Since single agent treatment is not expected to lead to long-term disease control, combination treatments must be tested. This must be done with care and proper planning since the number of patients with MPM who are suitable candidates for studies is relatively small.

\section{Conflict of interest statement}

Paul Baas is an advisor for Verastem, no funding for this paper has been received.

\section{References}

[1] Anonymous, The Helsinki Consensus report on diagnosis and attribution, Scand. J. Work Environ. Health 23 (1997) 311-318.

[2] J.C. Wagner, C.A. Sleggs, P. Marchand, Diffuse pleural mesothelioma and asbestos exposure in the North Western Cape Province, Br. J. Ind. Med. 17 (1960) 260-271.

[3] M. Carbone, B.H. Ly, R.F. Dodson, et al., Malignant mesothelioma: facts, myths, and hypotheses, J. Cell. Physiol. 227 (2012) 44-58.

[4] L. Stayner, L.S. Welch, R. Lemen, The worldwide pandemic of asbestos-related diseases, Annu. Rev. Public Health 34 (2013) 205-216.

[5] M.F. Muers, R.J. Stephens, P. Fisher, et al., Active symptom control with or without chemotherapy in the treatment of patients with malignant pleural mesothelioma (MS01): a multicentre randomised trial, Lancet 371 (2008) 1685-1694.

[6] N.J. Vogelzang, J.J. Rusthoven, J. Symanowski, et al., Phase III study of pemetrexed in combination with cisplatin versus cisplatin alone in patients with malignant pleural mesothelioma, J. Clin. Oncol. 21 (2003) 2636-2644.

[7] J.P. van Meerbeeck, R. Gaafar, C. Manegold, et al., Randomized phase III study of cisplatin with or without raltitrexed in patients with malignant pleural mesothelioma: an intergroup study of the European Organisation for Research and Treatment of Cancer Lung Cancer Group and the National Cancer Institute of Canada, J. Clin. Oncol. 23 (2005) 6881-6889.

[8] B. Woods, N. Paracha, D.A. Scott, et al., Raltitrexed plus cisplatin is cost-effective compared with pemetrexed plus cisplatin in patients with malignant pleural mesothelioma, Lung Cancer 75 (2012) 261-267.

[9] R.A. Damhuis, C. Schroten, J.A. Burgers, Population-based survival for malignant mesothelioma after introduction of novel chemotherapy, Eur. Respir. J. 40 (2012) 185-189.

[10] A. Scherpereel, P. Astoul, P. Baas, et al., Guidelines of the European Respiratory Society and the European Society of Thoracic Surgeons for the management of malignant pleural mesothelioma, Eur. Respir. J. 35 (2010) 479-495.

[11] E.A. Gehan, The determination of the number of patients required in a preliminary and a follow-up trial of a new chemotherapeutic agent, J. Chronic Dis. 13 (1961) 346-353.

[12] D. Hanahan, R.A. Weinberg, Hallmarks of cancer: the next generation, Cell 144 (2011) 646-674

[13] C. Manegold, J. Symanowski, U. Gatzemeier, et al., Second-line (post-study) chemotherapy received by patients treated in the phase III trial of pemetrexed plus cisplatin versus cisplatin alone in malignant pleural mesothelioma, Ann. Oncol. 16 (2005) 923-927.

[14] P. Taylor, B. Castagneto, G. Dark, et al., Single-agent pemetrexed for chemonaive and pretreated patients with malignant pleural mesothelioma: results of an International Expanded Access Program, J. Thorac. Oncol. 3 (2008) 764-771.

[15] P.A. Janne, A.J. Wozniak, C.P. Belani, et al., Pemetrexed alone or in combination with cisplatin in previously treated malignant pleural mesothelioma: outcomes from a phase IIIB expanded access program, J. Thorac. Oncol. 1 (2006) 506-512. 
[16] P. Ellis, A.M. Davies, W.K. Evans, et al., The use of chemotherapy in patients with advanced malignant pleural mesothelioma: a systematic review and practice guideline, J. Thorac. Oncol. 1 (2006) 591-601.

[17] J.B. Sorensen, S. Sundstrom, K. Perell, et al., Pemetrexed as second-line treatment in malignant pleural mesothelioma after platinum-based first-line treatment, J. Thorac. Oncol. 2 (2007) 147-152.

[18] J. Jassem, R. Ramlau, A. Santoro, et al., Phase III trial of pemetrexed plus best supportive care compared with best supportive care in previously treated patients with advanced malignant pleural mesothelioma, J. Clin. Oncol. 26 (2008) 1698-1704.

[19] J. Stebbing, T. Powles, K. McPherson, et al., The efficacy and safety of weekly vinorelbine in relapsed malignant pleural mesothelioma, Lung Cancer 63 (2009) 94-97.

[20] G. Giaccone, M.E. O’Brien, M.J. Byrne, et al., Phase II trial of ZD0473 as second-line therapy in mesothelioma, Eur. J. Cancer 38 (Suppl. 8) (2002) S19-S24.

[21] I. Tourkantonis, N. Makrilia, M. Ralli, et al., Phase II study of gemcitabine plus docetaxel as second-line treatment in malignant pleural mesothelioma: a single institution study, Am. J. Clin. Oncol. 34 (2011) 38-42.

[22] C. Porta, M. Zimatore, L. Bonomi, et al., Raltitrexed-oxaliplatin combination chemotherapy is inactive as second-line treatment for malignant pleural mesothelioma patients, Lung Cancer 48 (2005) 429-434.

[23] K. Fizazi, H. Doubre, T. Le Chevalier, et al., Combination of raltitrexed and oxaliplatin is an active regimen in malignant mesothelioma: results of a phase II study, J. Clin. Oncol. 21 (2003) 349-354.

[24] F. Vandermeers, P. Hubert, P. Delvenne, et al., Valproate, in combination with pemetrexed and cisplatin, provides additional efficacy to the treatment of malignant mesothelioma, Clin. Cancer Res. 15 (2009) 2818-2828.

[25] A. Scherpereel, T. Berghmans, J.J. Lafitte, et al., Valproate-doxorubicin: promising therapy for progressing mesothelioma. A phase II study, Eur. Respir. J. 37 (2011) 129-135.

[26] Y. Sekido, Molecular pathogenesis of malignant mesothelioma, Carcinogenesis 34 (2013) 1413-1419.

[27] W. Li, L. You, J. Cooper, et al., Merlin/NF2 suppresses tumorigenesis by inhibiting the E3 ubiquitin ligase CRL4(DCAF1) in the nucleus, Cell 140 (2010) 477-490.

[28] L.L. Garland, S. Ou, J. Moon, P. Mack, J. Testa, N. Tsao, et al., SWOG 0722: a phase II study of mTOR inhibitor everolimus (RAD 001) in malignant pleural mesothelioma (MPM), in: ASCO Annual Meeting, 2012 (abstract \#7083).

[29] A.J. Wagner, J.C. Bendell, S. Dolly, A first in human phase 1 study to evaluate GDC-0980, an oral P13K/mTOR inhibitor, administered QD in patients with advanced solid tumors, J. Clin. Oncol. 29 (2011), supplement (abstract \#3020).

[30] I.M. Shapiro, V.N. Kolev, C.M. Vidal, et al., Merlin deficiency predicts FAK inhibitor sensitivity: a synthetic lethal relationship, Sci. Transl. Med. 6 (2014) 237 ra268.

[31] M. Bott, M. Brevet, B.S. Taylor, et al., The nuclear deubiquitinase BAP1 is commonly inactivated by somatic mutations and 3p21.1 losses in malignant pleural mesothelioma, Nat. Genet. 43 (2011) 668-672.

[32] K.H. Ventii, N.S. Devi, K.L. Friedrich, et al., BRCA1-associated protein-1 is a tumor suppressor that requires deubiquitinating activity and nuclear localization, Cancer Res. 68 (2008) 6953-6962.

[33] L.M. Krug, H.L. Kindler, H. Calvert, et al., Vorinostat in patients with advanced malignant pleural mesothelioma who have progressed on previous chemotherapy (VANTAGE-014): a phase 3, double-blind, randomised placebo-controlled trial, Lancet Oncol. 16 (2015) 447-456.

[34] J. Folkman, Tumor angiogenesis: therapeutic implications, N. Engl. J. Med. 285 (1971) 1182-1186.

[35] S. Kumar-Singh, J. Weyler, M.J. Martin, et al., Angiogenic cytokines in mesothelioma: a study of VEGF, FGF-1 and -2, and TGF beta expression, J. Pathol. 189 (1999) 72-78.

[36] C. Linder, S. Linder, E. Munck-Wikland, et al., Independent expression of serum vascular endothelial growth factor (VEGF) and basic fibroblast growth factor (bFGF) in patients with carcinoma and sarcoma, Anticancer Res. 18 (1998) 2063-2068

[37] Y. Ohta, V. Shridhar, R.K. Bright, et al., VEGF and VEGF type C play an important role in angiogenesis and lymphangiogenesis in human malignant mesothelioma tumours, Br. J. Cancer 81 (1999) 54-61.

[38] S. Kumar-Singh, P.B. Vermeulen, J. Weyler, et al., Evaluation of tumour angiogenesis as a prognostic marker in malignant mesothelioma, J. Pathol. 182 (1997) 211-216.

[39] H.L. Kindler, T.G. Karrison, D.R. Gandara, et al., Multicenter, double-blind, placebo-controlled, randomized phase II trial of gemcitabine/cisplatin plus bevacizumab or placebo in patients with malignant mesothelioma, J. Clin. Oncol. 30 (2012) 2509-2515.

[40] S. Dubey, P.A. Janne, L. Krug, et al., A phase II study of sorafenib in malignan mesothelioma: results of Cancer and Leukemia Group B 30307, J. Thorac. Oncol. 5 (2010) 1655-1661.

[41] S.A. Laurie, A. Gupta, Q. Chu, et al., Brief report: a phase II study of sunitinib in malignant pleural mesothelioma. The NCIC Clinical Trials Group, J. Thorac. Oncol. 6 (2011) 1950-1954.

[42] T. Jahan, L. Gu, R. Kratzke, et al., Vatalanib in malignant mesothelioma: a phase II trial by the Cancer and Leukemia Group B (CALGB 30107), Lung Cancer 76 (2012) 393-396.

[43] N.P. Campbell, R. Kunnavakkam, N. Leighl, et al., Cediranib in patients with malignant mesothelioma: a phase II trial of the University of Chicago Phase II Consortium, Lung Cancer 78 (2012) 76-80.

[44] L.L. Garland, K. Chansky, A.J. Wozniak, et al., Phase II study of cediranib in patients with malignant pleural mesothelioma: SWOG S0509, J. Thorac. Oncol. 6 (2011) 1938-1945.

[45] A.K. Nowak, M.J. Millward, J. Creaney, et al., A phase II study of intermittent sunitinib malate as second-line therapy in progressive malignant pleural mesothelioma, J. Thorac. Oncol. 7 (2012) 1449-1456.

[46] W.A. Buikhuisen, J.A. Burgers, A.D. Vincent, et al., Thalidomide versus active supportive care for maintenance in patients with malignant mesothelioma after first-line chemotherapy (NVALT 5): an open-label, multicentre, randomised phase 3 study, Lancet Oncol. 14 (2013) 543-551.

[47] V. Gregorc, P.A. Zucali, A. Santoro, et al., Phase II study of asparagine-glycine-arginine-human tumor necrosis factor alpha, a selective vascular targeting agent, in previously treated patients with malignant pleural mesothelioma, J. Clin. Oncol. 28 (2010) 2604-2611.

[48] A.K. Nowak, C. Brown, M.J. Millward, et al., A phase II clinical trial of the vascular disrupting agent BNC105P as second line chemotherapy for advanced malignant pleural mesothelioma, Lung Cancer 81 (2013) 422-427.

[49] A. Mathy, P. Baas, O. Dalesio, et al., Limited efficacy of imatinib mesylate in malignant mesothelioma: a phase II trial, Lung Cancer 50 (2005) 83-86.

[50] A.Z. Dudek, H. Pang, R.A. Kratzke, et al., Phase II study of dasatinib in patients with previously treated malignant mesothelioma (cancer and leukemia group B 30601): a brief report, J. Thorac. Oncol. 7 (2012) 755-759.

[51] A. Destro, G.L. Ceresoli, M. Falleni, et al., EGFR overexpression in malignant pleural mesothelioma: an immunohistochemical and molecular study with clinico-pathological correlations, Lung Cancer 51 (2006) 207-215.

[52] L.L. Garland, C. Rankin, D.R. Gandara, et al., Phase II study of erlotinib in patients with malignant pleural mesothelioma: a Southwest Oncology Group Study, J. Clin. Oncol. 25 (2007) 2406-2413.

[53] D.M. Jackman, H.L. Kindler, B.Y. Yeap, et al., Erlotinib plus bevacizumab in previously treated patients with malignant pleural mesothelioma, Cancer 113 (2008) 808-814

[54] L. Calabro, A. Morra, E. Fonsatti, et al., Tremelimumab for patients with chemotherapy-resistant advanced malignant mesothelioma: an open-label, single-arm, phase 2 trial, Lancet Oncol. 14 (2013) 1104-1111.

[55] L. Calabro, A. Morra, F.E. Cutaia, O. Fazio, C.R. Danielli, et al., A phase 2 single-arm study with tremelimumab at an optimized dosing schedule in second-line mesothelioma patients, J. Clin. Oncol. 32 (2014), supplement (abstract \# 7531).

[56] E.W. Alley, R. Molife, A. Santoro, K. Becey, S. Yuan, D. Cheng et al., Clinical safety and efficacy of pembrolizumab (MK-3475) in patients with malignant pleural mesothelioma: preliminary results from KEYNOTE-001, in: AACR Annual Meeting, 2015 (abstract \#CT103).

[57] K. Chang, I. Pastan, Molecular cloning of mesothelin, a differentiation antigen present on mesothelium, mesotheliomas, and ovarian cancers, Proc. Natl. Acad. Sci. U. S. A. 93 (1996) 136-140.

[58] R. Hassan, T. Bera, I. Pastan, Mesothelin: a new target for immunotherapy, Clin. Cancer Res. 10 (2004) 3937-3942.

[59] P.S. Chowdhury, J.L. Viner, R. Beers, et al., Isolation of a high-affinity stable single-chain Fv specific for mesothelin from DNA-immunized mice by phage display and construction of a recombinant immunotoxin with anti-tumor activity, Proc. Natl. Acad. Sci. U. S. A. 95 (1998) 669-674.

[60] R. Hassan, A.C. Miller, E. Sharon, et al., Major cancer regressions in mesothelioma after treatment with an anti-mesothelin immunotoxin and immune suppression, Sci. Transl. Med. 5 (2013), 208ra147.

[61] D.A. Fennell, C. McDowell, S. Busacca, G. Webb, B. Moulton, A. Cakana, et al. Phase II clinical trial of first or second-line treatment with bortezomib in patients with malignant pleural mesothelioma, J. Thorac. Oncol. 7 (9) (2012) 1466-1470. 